This item was submitted to Loughborough's Research Repository by the author.

Items in Figshare are protected by copyright, with all rights reserved, unless otherwise indicated.

\title{
Cities as networks within networks of cities: the evolution of the city/firm- duality in the world city network, 2000-2010
}

PLEASE CITE THE PUBLISHED VERSION

http://dx.doi.org/10.1111/tesg.12097

\section{PUBLISHER}

Wiley-Blackwell (@ Royal Dutch Geographical Society KNAG)

VERSION

AM (Accepted Manuscript)

\section{PUBLISHER STATEMENT}

This work is made available according to the conditions of the Creative Commons Attribution-NonCommercialNoDerivatives 4.0 International (CC BY-NC-ND 4.0) licence. Full details of this licence are available at: https://creativecommons.org/licenses/by-nc-nd/4.0/

\section{LICENCE}

CC BY-NC-ND 4.0

\section{REPOSITORY RECORD}

Liu, Xingjian, Ben Derudder, Frank Witlox, and Michael Hoyler. 2019. "Cities as Networks Within Networks of Cities: The Evolution of the City/firm-duality in the World City Network, 2000-2010". figshare. https://hdl.handle.net/2134/16509. 


\title{
Cities as networks within networks of cities: the evolution of the city/firm-duality in the world city network, 2000-2010
}

Xingjian Liu ${ }^{1}$, Ben Derudder ${ }^{2}$, Frank Witlox ${ }^{2}$, Michael Hoyler ${ }^{3}$

1. Department of Geography and Earth Sciences, University of North Carolina at Charlotte, USA.Email: xliu36@uncc.edu

2. Geography Department, Ghent University, Belgium. Email: ben.derudder@ugent.be; frank.witlox@ugent.be

3. Department of Geography, Loughborough University, UK. Email: M.Hoyler@lboro.ac.uk

\begin{abstract}
We explore the temporal evolution of cities and firms (i.e. both modes) in a two-mode intercity corporate network formed by 50 leading advanced producer service firms across 154 cities for the years 2000 and 2010. Drawing upon one-mode network projection and three network centralities, we assess the shifting positions of individual cities and firms in the one-mode intercity and interfirm networks. Major findings include: (1) the intercity network is more stable and hierarchical than the interfirm network; (2) brokerage functions, as captured by betweenness centrality, remain highly uneven for both cities and firms. For example, New York and London's distinct positions as the world's leading producer service centres remain intact; and (3) regional and sectoral tendencies are evident in terms of growth rates of centralities.
\end{abstract}

\section{Key words:}

Duality; two-mode networks; intercity corporate network; temporal evolution

\footnotetext{
${ }^{1}$ Our title is appropriately based on Berry's (1964) classic paper, in which he emphasised that the study of cities' position in a 'system' cannot be separated from the study of what goes in within these cities. The analytical approach advanced in this paper reflects the spirit of Berry's message.
} 


\section{INTRODUCTION}

It seems fair to state that Peter Taylor's (2001) formal specification of the 'world city network' (WCN) as an 'interlocking network' has been a milestone in the world cities literature. In this 'interlocking world city network model' (IWCNM), cities are deemed connected through the flows of information, knowledge, capital, people, etc. generated within the office networks of globalised advanced producer services (APS) firms. Drawing on this IWCNM specification and a series of concomitant data gatherings to 'feed' the model, Taylor and colleagues from the Globalisation and World Cities (GaWC) research network have provided detailed descriptions of the connectivity of cities in the WCN (e.g. Taylor et al. 2011).

Parallel to the APS analyses of the GaWC group (www.lboro.ac.uk/gawc), other approaches and strategies have been developed to study WCN formation. This includes studies of global infrastructure networks such as airline passenger networks (e.g. Smith \& Timberlake 2001), maritime networks (e.g. Ducruet 2013), and Internet backbone networks (e.g. Rutherford et al. 2004), but also strategies that are more akin to the GaWC approach in that the analytical focus is on the geographies of corporate networks (e.g. Hoyler \& Watson 2013; Krätke 2014; for overviews, see Liu \& Derudder, 2012a; Neal, 2013). The most common approach in this regard has been empirical research that focuses on headquarter-subsidiary relations within the corporate structures of multinational corporations (MNCs), for example, the work of Alderson \& Beckfield (2004), Wall \& van der Knaap (2011), and Rozenblat \& Pumain (2007).

The particular appeal of the research drawing on Taylor's IWCNM can probably be traced back to its theoretical foundations. In a literature that had long been flawed by a combination of eclecticism and fuzziness, Taylor (2001) presented the IWCNM in the context of the well-established literature on social network analysis. In addition, the assumptions underlying the IWCNM specification were not merely asserted, but explained in the context of Sassen's (1991) research on 'global cities' and Castells' (2001) writings on 'the rise of the network society'. Nonetheless, some of the tenets of the IWCNM specification have - albeit somewhat belatedly - come under close scrutiny in recent years 
(e.g. Nordlund 2004; Beckfield \& Alderson 2006; Neal 2011, 2012, 2013; Hennemann \& Derudder 2013). One issue that has been raised in this context, and which will also be the core focus of this paper, is that most of the research drawing on the IWCNM does not make appropriate use of all the information contained in the original datasets.

Taylor's (2001) specification of the WCN essentially starts off as a so-called 'two-mode network' or 'dual network' (Breiger 1974; Liu \& Derudder 2012b). A two-mode network consists of two disjointed sets of nodes, whereby the primary data connect nodes of both sets. The starting point of GaWC's analyses are indeed two-mode networks, as the datasets consist of two disjointed sets of nodes (world cities and globalised APS firms) whereby the primary data consist of links connecting nodes of the different sets (the presence of globalised APS firms in world cities). In principle, two one-mode networks can be projected from GaWC's two-mode datasets (Neal 2008), that is, a city-by-city adjacency matrix (such as the IWCNM as it is commonly studied) and a firm-by-firm adjacency matrix (a dataset detailing the co-location of firms in cities). As a corollary, the IWCNM essentially tells only 'half' of the story, that of the cities. Although this may seem warranted or even logical given that the research focuses on city network formation, network analysts have lamented such a one-sided approach to two-mode networks by pointing to the information loss this engenders (e.g. Breiger 1974; Latapy et al. 2008).

A two-mode perspective on WCN-formation not only recognises that (1) inter-city networks emerge from the daily exchanges amongst branches of a globalised APS firm in different cities, but also that (2) inter-firm networks emerge from, say, information sharing, cooperation, and innovation diffusion among different APS firms in a given city (e.g. Bathelt et al. 2004). Despite its appeal and merit, then, the IWCNM does not do full justice to this 'duality of cities and firms' (cf. Neal 2008) in the formation of WCNs, as the information on how APS firms organise themselves in cities is cast-off: information on which firms co-locate in what cities may be crucial to our understanding of WCN formation, but is being discarded. The purpose of this paper is to complement the research drawing on the IWCNM by presenting a two-mode analysis of the world city/APS firm-nexus as measured in the GaWC data. Neal (2008) has presented such an analysis based on GaWC data for the year 2000. 
Here we extend his work by adding a longitudinal element to the analysis, exploring changes in both modes of WCN-formation as measured for 2000 and 2010.

The remainder of this paper is organised as follows. In the next section, we spell out in more detail the differences between a one-mode and a two-mode analysis of the WCN. We then describe our datasets containing information on the presence of 50 globalised APS firms in 154 world cities for the years 2000 and 2010. The ensuing section presents our measurement framework, which entails a description of different centrality measures to analyse the position of nodes in networks. This is followed by a discussion of our results, after which our paper is concluded with a summary of our main findings and suggestions for further research.

\section{THE IWCNM: A TWO-MODE NETWORK}

As noted, Taylor's (2001) specification of the WCN essentially starts off as a so-called 'twomode network', which is characterised by connections between two separate sets of nodes (cities and firms). By contrast, in more conventional one-mode networks, actors are directly interlinked (e.g. cities connected by airline flows). The gist of two-mode networks is that there is no direct linkage within the same set of nodes (i.e. between cities or between firms): researchers simply know which firms are in what cities, and which cities house what firms. Such city-by-firm datasets have been collected as intermediate products in WCN studies that approximate urban networks through an analysis of the organisational structures of multinational enterprises (e.g., Alderson \& Beckfield 2006; Hoyler et al. 2008; Wall 2009; Jacobs et al. 2011).

To facilitate our discussion of the implications for the analysis of such data, in what follows we will make use of a sample city-by-firm matrix (Figure 1), excerpted from the GaWC 2000 dataset. This valued matrix describes a two-mode network consisting of five firms (Ernst and Young, HSBC, Jones Day, Boston Consulting, BBDO Worldwide) across five cities (New York, London, Paris, Tokyo and Beijing). The values in the matrix feature the 'linkage' between 
cities and firms: The matrix values range from 0 to 5 , where 0 indicates absence of a firm, 5 indicates the presence of the firm's headquarters, and the values in-between are a measure of the relative importance of an office in a firm's network. For example, BBDO Worldwide is headquartered in New York, and has a major office (representing a value of 4) in London and a middle-of-the-road office (representing a value of 2 ) in Beijing.

\section{[FIGURE 1 ABOUT HERE]}

To date, most empirical analyses of two-mode networks in general and intercity corporate networks in particular have followed one of two major directions: (1) a direct two-mode examination of the data; or (2) its conversion into a one-mode network.

The direct two-mode network approach allows for a direct examination of the duality, using all the information contained within the city-by-firm data matrix, namely, cities and firms are studied simultaneously. In its simplest form, the two-mode approach treats the city-byfirm network as a multivariate dataset and applies different multivariate statistical methods to reveal patterns in the data (e.g. Taylor 2004; Taylor \& Derudder 2004; Taylor et al. 2013a). However, such a straightforward multivariate analysis implicitly falls short of accounting for the interdependence among individual firms' locational strategies, that is, the assumptions of many statistical models require data points to be independent. More advanced two-mode network analyses address this interdependence issue and move on to understanding the underlying dynamics of intercity corporate networks (Liu et al. 2013a).

However, the interpretation of results of two-mode network analysis is not very intuitive, and may therefore be less attractive for urban scholars. For example, the definitions of betweenness and closeness centralities of two-mode networks (Borgatti \& Everett 1997) involve both embodied (e.g. firms' presence in cities) and intangible flows (e.g. technological spillovers between firms), making it difficult to interpret the importance of individual cities and firms in a single framework.

A more straightforward and common way to analyse the two-mode city-by-firm network is to derive city-to-city and firm-to-firm one-mode networks through network projections. 
While the direct two-mode approach analyses cities and firms simultaneously, the onemode projection allows us to deal with both modes separately. On the one hand, connections in the projected city-to-city network are forged by the location of offices of an APS firm in different cities, and represent potential intercity connections (Taylor 2001). On the other hand, two firms are deemed as connected in the firm-to-firm network if they colocate in the same cities, and the extent of co-location suggests the potential for inter-firm information exchange (Neal 2008). Bathelt et al. (2004) claim that the knowledge learning and generation in contemporary knowledge economy are achieved through local interactions ('buzz') as well as knowledge channelled from translocal communications ('pipelines'). Therefore, a firm may benefit from co-locating with others (joining local 'buzz') and expanding office networks (making extensive 'pipelines'), which often lead to colocations between firms in multiple cities. Moreover, firms' locational strategies are often interrelated (e.g. mimicking and following one another; Liu et al. 2013a).

Both types of one-mode networks are indeed examined in the economic geography and regional studies literature. For instance, research on urban systems focuses on cities as interlocked by infrastructure and multi-locational firms (e.g. Mitchelson \& Wheeler 1994), while research on regional clustering focuses on inter-firm networks formed by co-location of firms in cities or regions (e.g. Polenske 2004; Huber 2011).

[FIGURE 2 ABOUT HERE]

[FIGURE 3 ABOUT HERE]

The major drawback of using one-mode projections is that it often inflates the number of linkages in the network: it tends to generate a very dense city connectivity matrix that is hard to handle with network analysis techniques (Latapy et al. 2008). For example, the onemode intercity and interfirm networks projected from the pedagogic example above represent two fully connected networks (Figure $2 \mathrm{~b}$ and $3 \mathrm{~b}$ ). Conventional approaches adopted to alleviate this issue include applying thresholds and alternative network projections (Neal 2013, Neal 2014; Hennemann \& Derudder, 2013). 
Formally, the projection from the two-mode city-by-firm network into the city-to-city and firm-to-firm networks can be defined as (Neal 2008) ${ }^{2}$ :

$$
\begin{aligned}
& E(c)=V^{*} V^{t} \\
& E(f)=V^{t} * V
\end{aligned}
$$

Where $V$ and $V^{t}$ represent the original city-by-firm data matrix and its transpose; $E(c)$ is a one-mode network capturing the intensity of potential intercity connections; $E(f)$ is another one-mode network measuring the intensity of potential interfirm connections.

A key point is that Taylor's (2001) interlocking WCN model is essentially a projection from the original intercity corporate network, namely, equation (1). In the context of our empirical focus, the assumption behind (1) and (2) is that the more important an office of firm $j$ in city $i$, the more links there will be with offices in other cities of firm j's network as well as with offices of other firms in city i (i.e. a simple interaction model). For the intercity network, the limiting case is a city that shares no firms with any other city so that all of its service value products in equation (1) are 0 . Similarly, if a firm does not co-locate with another firm, it will have no connections in the interfirm network produced by equation (2). Such projection implies a 'brute force' process (Neal 2013) where intercity linkages are a function of cities' sizes as represented by the number of firms in individual cities. Similarly, interfirm connections are in part determined by firms' absolute sizes as measured by the number of cities in which individual firms locate.

\section{DATA}

To engage in a comprehensive analysis of how positions of firms and cities in the WCN have changed between 2000 and 2010, we make use of the GaWC datasets for 2000 and 2010 to

\footnotetext{
${ }^{2}$ Similar to gravity/spatial interaction models, the current projection functions assume that links in the projected city/firm networks are a multiplicative function of city/firm importance. Link weights can also be produced by additive, strongest-link, or weakest-link functions.
} 
explore the evolution of both intercity and interfirm networks. The two-mode GaWC data details the office networks of large professional, financial and creative service firms in cities throughout the settled world. These data collections are described in detail in Taylor et al. (2002) for the year 2000 and in Taylor et al. (2013a) for the year 2010, and will be summarised here as they provide the input to our subsequent analysis. The data collection involved three major steps:

\section{Selection of cities and firms}

In 2000, global APS firms were defined as firms with offices in 15 or more different cities, including at least one in northern America, western Europe and Pacific Asia. Firms meeting this criterion were selected from rankings of leading firms in different service sectors. 100 firms were identified in six sectors: 18 in accountancy, 15 in advertising, 23 in banking/finance, 11 in insurance, 16 in law, and 17 in management consultancy. Selecting cities was based upon previous GaWC experience in researching global office networks and also included all capital cities. A total of 315 cities were selected. The end result is a 315 cities by 100 firms matrix.

In 2010, a much larger data collection was performed. A more robust firm selection method was imposed by including all top firms in individual sectors for which data were available. The separate banking/finance and insurance sectors in the 2000 dataset were combined, and the top 75 such firms were selected as ranked in the Forbes composite index, a measure that combines rankings for sales, profits, assets and market value. For each of the other four of the previously studied services - accountancy, advertising, law and management consultancy -the top 25 firms were included based on sectoral rankings (Derudder et al. 2010). Overall, the number of firms was increased from 100 to 175 . In addition, the number of cities was increased to 526, adding among others many fastgrowing and economically important cities from emerging economies (e.g. China and India). The end result is a 526 cities by 175 firms matrix. 


\section{Determination of service values}

The next step determines values in the city-by-firm matrix. The GaWC approach to assign 'service values' focuses on two features of a firm's office(s) in a city as shown on their corporate websites: first, office size (e.g. number of practitioners), and second, extralocational office functions (e.g. regional headquarters). Information for every firm is simplified into service values ranging from 0 to 5 . The city housing a firm's headquarters scores 5 , a city with no office of that firm scores 0 . An 'ordinary' or 'typical' office of the firm scores 2 . With something missing (e.g. no partners in a law office), the score is reduced to 1. Particularly large offices score 3 and those with important extra-territorial functions (e.g. regional headquarters) score 4 . All such assessments are made firm by firm.

\section{Ensuring data consistency}

As the sets of cities and firms collected in 2000 and 2010 are not entirely identical, the challenge is to measure actual structural changes in the WCN rather than changes in the data gatherings. Here we take the easiest route by restricting our analysis to (1) the 50 firms that have 'strong' linkages (see below) in the projected inter-firm network in 2000 and 2010; and (2) the 154 cities that have 'strong' linkages (see below) in the projected intercity network in 2000 and $2010^{3}$. As a consequence, the final dataset consists of two 154 citiesby-154 cities intercity and two 50 firm-by-50 firm inter-firm networks. Although this restriction causes a loss of data, it provides necessary consistency for a longitudinal analysis.

And finally, we will also look at changes in the connectivity of cities and firms at a higher level of abstraction, that is, regions (for cities) and sectors (for firms), which may reduce overall network complexity and highlight major patterns. In order to discern regional tendencies in the evolution of intercity corporate networks, we adopt the regionalisation scheme in Taylor et al. (2013a), and assign individual cities into one of the nine major world regions: Europe (49 cities), North America (26), Latin America (22), Pacific Asia (15), Middle

\footnotetext{
${ }^{3}$ Ensuring cities and firms are 'connected' in both years would avoid problems of calculating centrality scores for isolated nodes and generate more comparable centrality scores. This limits our analysis to cities that are already 'connected' in 2000, focusing less on cities that are isolated in 2000 but merged into the network in 2010.
} 
East \& North Africa (14), South Asia (9), Sub-Saharan Africa (8), Australia (7), and Eurasia (4). Similarly, firms are labelled with their sectoral affiliations, namely, accountancy (14 firms), consultancy (11), advertising (10), banking and finance (8), and law (7).

\section{METHODS}

For both years, we derive an intercity network and an interfirm network using equations (1) and (2). We employ the constant thresholding dichotomisation to circumvent the issue of fully-connected projected networks. An empirical decision is made to consider individual linkages to be strong enough and set to 1 if they are at least 10 per cent of the strongest linkage in corresponding networks and 0 otherwise (a sensitivity analysis is provided in the appendix to justify the use of this 10 per cent threshold; see Butts 2009 for a theoretical discussion of sensitivity analysis). Although it is clear that this dichotomisation creates issues such as loss of information (Opsahl \& Panzarasa 2009), dichotomised networks allow for a wide range of network analysis techniques (not limited to the centralities employed in the current context) as well as backward comparisons with previous studies that use binary networks (Neal 2008). This leaves us with a 154-by-154 intercity network and a 50-by-50 interfirm network for 2000 and 2010. Our projection and thresholding methods reflect a theoretical 'brute force' perspective on intercity/interfirm interactions (i.e. stronger connections are more important, as they connect cities of sheer economic size), which has been employed in most previous analyses. We adopt this conventional projection method to ensure a consistent comparison with previous findings. Nevertheless, we note that alternative theoretically-driven projections, such as a 'sorting process' method during which firms are sorted into cities (Neal 2013), are suitable for revealing other aspects of world city formation. In addition, we do not employ other projection methods (Alderson \& Beckfield 2004; Hennemann \& Derudder 2013) that (1) are suitable to derive intercity relations but not interfirm connectivity; (2) produce sparse intercity networks in the case of a rather limited number of firms; and/or (3) restrain the number and types of offices to be included in the analysis. 
We assess the network positions of individual cities and firms with three network centrality measures: degree, closeness, and betweenness centrality. Following Alderson et al. (2010), we illustrate the implications of these centrality measurements with pedagogic networks. The two networks (Figure 4) represent connections between cities and firms if we treat the nodes as cities and firms, respectively. The star network (Figure 4a) exhibits a hierarchical scenario, in which a firm or city with the position of A clearly holds a more central position than other nodes in the network. In contrast, the circle network (Figure $4 \mathrm{~b}$ ) represents a flat network, with all nodes attaining the same structural positions.

\section{[FIGURE 4 ABOUT HERE]}

Degree centrality measures individual nodes' direct linkages to other nodes in the network. For example, node $\mathrm{A}$ in the star network has an advantageous position as it has more access to other nodes in the network. For the intercity network, this means that the city in position A has more peers to connect with than the other three cities $(B, C, D)$, that is, city $A$ has a larger pool of potential connections. Similarly, firms with more connections tend to have greater possibilities for interaction, such as co-operation and information sharing. By contrast, all nodes in the circle network have exactly the same number of linkages and are therefore equally positioned in the network.

Closeness centrality measures individual nodes' inverse distances to all other nodes. For the intercity network, cities with larger closeness have more direct and indirect access to other cities, whereas a larger closeness in the interfirm network reflects less intermediate steps/time that a firm needs to access information/innovations generated by other firms. In this regard, node $\mathrm{A}$ in the star network is advantaged and has a larger closeness score: its sum of inverse distance to other nodes $(1 / 1+1 / 1+1 / 1=3)$ is greater than that of nodes B-D $(1 / 2+1 / 2+1 / 1=2)$. By contrast, all four nodes $(A-D)$ in the circle network have equal closeness scores $(1 / 1+1 / 1+1 / 2=2.5)$.

Betweenness centrality captures nodes' tendency for performing brokerage roles, i.e. controlling or facilitating interactions between other nodes. In the star-like intercity network, business connections between cities B-D (or B-C or C-D) cannot bypass city A, 
whereas city A requires no intermediate cities to conduct business with other cities. Hence A has a betweenness of 3 for the entire network, whereas the betweenness centrality of $B$, $C$, and $D$ equals 0 . Similarly, firms in positions $A$ can control the exchange of information and innovation between other pairs of firms, achieving a certain degree of monopoly on information spillovers. In comparison, nodes A-D in the circle network are equally advantaged/disadvantaged in controlling flows between other pairs of nodes: all nodes have a betweenness centrality of 1 .

\section{RESULTS}

Thus far, we have described (1) the two-mode network underlying Taylor's IWCNM and the potential offered by exploring both modes of the intercity corporate network, (2) the transformation of the data to arrive at consistent sets of intercity and interfirm networks for 2000 and 2010, and (3) the key tenets of three commonly used centrality measures in network analysis. Combined, this gives us the opportunity to assess the following questions, which will be used to organise the discussion of our results:

- How have intercity and interfirm networks changed over time?

- Have intercity and interfirm networks become more or less hierarchical?

- What are the regional and sectoral tendencies in the evolution of intercity and interfirm networks?

\section{How have intercity and interfirm networks changed?}

Before entering the discussion of changes in the intercity corporate network between 2000 2010 , it is helpful to take a small detour and examine the robustness of our analysis by assessing whether city and firm rankings are consistent with previous studies (Table 1 and $2)^{4}$. On the one hand, cities' ranks for 2000 and 2010 are largely in line with those identified based on the fuller GaWC datasets (Taylor et al. 2002, 2014; Derudder et al. 2010) and/or

\footnotetext{
${ }^{4}$ For ease of interpretation, all centrality scores are normalised. An overview of normalisation of centrality scores in one- and two-mode networks can be found in Borgatti \& Everett (1997).
} 
different intercity networks (Smith \& Timberlake 2001; Alderson \& Beckfield 2010). For example, our analysis confirms that major cities in the emerging economies (e.g. Dubai and Mumbai) rise into the top of the global urban hierarchy, whereas a number of established first tier cities (e.g., New York, London, Hong Kong, and Paris) maintain their leading positions (Table 1). On the other hand, the rankings of firms reported here are also consistent with previous findings (Neal 2008), with banks and accounting firms assuming leading positions in the interfirm network (Table 2). Therefore, despite using a subset of the GaWC dataset, our analysis of both modes in the intercity corporate network appears to generate intercity and interfirm networks that largely coincide with previous studies.

[TABLE 1 ABOUT HERE]

[TABLE 2 ABOUT HERE]

While there seems to be little variation among the top cities in the three centrality rankings for individual years, the inequalities within individual rankings vary, suggesting 'a hierarchy of hierarchies' (Neal 2008). Note that the use of 'hierarchy' in the context of global urban/firm networks is different from that in network science: the former focuses on the uneven distribution of centralities among nodes, while the latter is more related to directions of network linkages. The Gini coefficients ${ }^{5}$ of closeness centrality are smallest (Table 4), reflecting that cities/firms can reach other with a few intermediate steps. Degree centralities for both cities and firms are more hierarchical, as there are nonetheless sizable differences in the level of integration in the networks. The unevenness within betweenness centrality is the most extreme, because there are only a few cities and firms that are privileged with brokerage roles in the intercity and interfirm networks (Neal 2008).

Our results suggest that the global firm network has undergone extensive change, as the correlations between centrality scores in 2000 and 2010 are moderate at best (Table 3; see also QAP correlations in the appendix). In comparison, the global urban hierarchy is more

\footnotetext{
${ }^{5}$ Larger Gini coefficients represent greater inequality among centrality scores. A Gini coefficient of 0 indicates total equality, whereas a value of 1 suggests extreme inequality. Gini coefficient is often used to measure income inequality, and we adopt it here to measure the unequal distribution of centralities among cities/firms.
} 
stable in terms of correlation between centrality scores in different years. With limited supplementary data, the task of identifying the determinants of observed changes goes beyond the scope of the current paper. However, a few conjectures can be made: these changes may reflect recent upheavals in the global geo-economic structure, or they may reflect long-term organisational changes of producer services firms (e.g. mergers, acquisitions, joint ventures, and other forms of strategic alliances).

\section{[TABLE 3 ABOUT HERE]}

The most notable feature in this transition is the overall integration in intercity and interfirm networks during the period $2000-2010$, as evidenced by a number of related indicators: the average degree centralities for cities and firms increase substantially between 2000 and 2010. With the 10 per cent threshold, the interfirm network is close to fully connected in 2010 (Table 3). Individual cities are able to establish more direct economic connections with other cities, whereas firms are able to benefit from interacting directly with a larger number of firms. This enhanced integration shrinks distances among cities and firms, so that closeness centrality increases for both cities and firms. Furthermore, average betweenness centralities decline for interfirm networks, as fewer firms occupy brokerage positions when interfirm networks become more connected (Table 7). Similar observations can be made for intercity networks: As former 'peripheral' regions are rapidly integrating into the global urban network (at least those produced by APS firms), North American and European cities' betweenness centralities relatively decline.

As noted earlier, the urban hierarchy is more stable and steeper than the firm hierarchy. The correlations between centrality scores of cities during 2000-2010 are generally greater than those of firms, that is, the shuffling of ranks is more volatile in the interfirm network (Table 3). For example, 22 firms entered the top fifteen positions in centrality rankings during 2000-2010. The most noticeable example of stability is the consistent dominance of New York and London (NY-LON) in the intercity network (Neal 2008; Taylor et al. 2013a). Despite the emergence of an increasingly connected intercity network, NY-LON consistently ranks atop all centrality rankings (Table 1 ). NY-LON's dominance is especially evident in the ranking of betweenness centrality: New York and London are the only true brokerage nodes, 
coordinating a sizeable amount (around 10 per cent for 2010) of all intercity connections in both years. By contrast, no firm exhibits a similar dominance in the interfirm network.

\section{[TABLE 4 ABOUT HERE]}

\section{Have intercity and interfirm networks become more or less hierarchical?}

There are, in principle, different conjectures about the global distribution of connectivity in the new urban hierarchy. At one end of the spectrum, the intercity network can be expected to become more hierarchical with command-and-control functions of the global economy increasingly concentrating in a limited set of cities (Friedmann 1986; Sassen 2001). At the other end, a lessening of hierarchical tendencies in the global urban arena has been suggested, with cities in the Global South quickly integrating into the world city network as office networks have extended into other regions (Derudder et al. 2010). Therefore, we assess the temporal changes of inequality among cities' connectivity by tracing Gini coefficients of centrality rankings in different years.

The results in Table 4 point to mixed tendencies. On the one hand, the distributions of degree and closeness centrality become more even during 2000-2010, suggesting that cities become similar in terms of number of strong economic linkages as well as average distances to others. On the other hand, the unevenness among betweenness centralities remains rather constant, despite more cities integrating into the world city network and making average betweenness centrality scores decline.

There are also different hypotheses about hierarchical and heterarchical processes in the interfirm network. On the one hand, firms with more branches in 2000 tend to continue their expansive strategies, achieving a higher level of integration into the interfirm network and thus potentially amassing additional structural advantage (Liu et al. 2013a). For example, acquisition and mergers among firms usually concentrate market power into fewer players (Neal 2008). On the other hand, while globalised spatial strategies were just for the 'happy few' at the dawn of this century (Wall et al. 2011), more firms are now equipped/motivated to pursue a worldwide presence, narrowing the gaps between firms' 
connectivity and creating a flatter firm hierarchy. Further complications are brought about by the recent global economic crisis, during which many financial services as well as other advanced producer services have undergone substantial reorganisation.

Our analysis (Table 4) suggests that while the interfirm network is becoming more integrated and even, the brokerage/control functions, as captured by betweenness centrality, remain modestly unequal among firms. The decreasing inequality among degree and closeness centralities is consistent with the overall rise of network connectivity. Meanwhile, the decreasing but still sizeable Gini coefficients for betweenness centralities suggest that the power to control information sharing and diffusion remains modestly concentrated in the integrated interfirm network.

While both networks exhibit a mix of hierarchical and heterarchical processes, the inequality in the intercity network tends to be greater than that in interfirm networks. This confirms previous observations that a small set of strategic places retain crucial positions in the provision of advanced producer service in contemporary globalisation (Neal 2008; Taylor et al. 2014).

What are the regional and sectoral tendencies in the evolution of intercity and interfirm networks, respectively?

Regional and sectoral tendencies in the evolution of intercity and interfirm networks are assessed based on the average centralities of individual regions and sectors (Table 5). Where regionality has been a persistent feature of intercity networks (Taylor et al. 2001, 2013a), centralities of different regions in intercity networks have also been found to be converging (Alderson et al. 2010; Mahutga et al. 2010): the regional inequalities among average centralities are becoming less steep, i.e. erstwhile 'peripheral' regions are catching up in terms of their integration in APS networks. Cities in Middle East \& North Africa (MENA), South Asia, and Eurasia, for instance, are characterised by above-average growth in centrality scores (Table 6). The claim about the rise of MENA is particularly robust, as more cities from this region have been included in our sample than other regions experiencing growth (e.g. South Asia and Sub-Saharan Africa). In addition, leading cities in MENA, such as 
Dubai, have risen considerably in city rankings (see Table 1). However, the unevenness for the betweenness centrality is still the most pronounced one among the three centrality measures (Table 5) - despite that overall betweenness centralities are decline, the command-and-control functions of advanced producer servicing have largely concentrated in the worlds' three major urban arenas: North America, Europe, and Pacific Asia.

Law and consultancy firms appear to enjoy above-average growth in closeness and degree centrality and relatively less decline in betweenness centrality (Table 7). Advertising and accounting firms seem to endure slower expansion rates in the selected 154 cities. When these changes of centralities in law and consultancy are jointly examined with the geographic distribution of individual firms (Rossi \& Taylor 2006; Taylor et al. 2013a), these diverging growth trends in different sectors may represent distinct globalisation processes, extensive and intensive (Taylor et al. 2013b). This dichotomisation builds upon a 'coreperiphery' perception of the world-system, which consists of a densely interconnected 'core' and many less-connected 'peripheries' (Alderson \& Beckfield 2004). Extensive globalisation is characterised by linkages between the core (e.g. NY-LON) and periphery (e.g. the Global South), whereas intensive globalisation focuses more on the intensification of linkages within the core. Accounting firms often contribute to extensive globalisation, as they usually have very large office networks. In fact, the largest firms in our dataset (e.g. KPMG, Pricewaterhouse, and Deloitte), in terms of number of branches, are mainly accounting firms. Advertising and accounting firms under investigation have undergone extensive expansion in the selected 154 cities $^{6}$ at the beginning of our study period, thus appearing to be expanding less aggressively during 2000-2010. On the contrary, the office networks of management consultancy and law firms are often concentrated in the world's major urban arenas, and are thus more involved in intensive globalisations (Taylor et al. 2014).

\footnotetext{
${ }^{6}$ In a relative sense, the selected 154 cities could be deemed as an enlarged 'core' of the global economy as these cities are connected (have strong economic relationships) for both years.
} 


\section{CONCLUSIONS}

In this paper, we explored the temporal evolution of both cities and firms in a two-mode intercity corporate network formed by 50 leading advanced producer service firms across 154 cities. Drawing upon one-mode network projection and three network centrality measures, we assess how individual cities and firms evolve in intercity and interfirm networks. Our dataset is derived from GaWC datasets collected in 2000 and 2010.

Our analysis suggests that the global urban and firm networks contained in GaWC data have undergone extensive changes between 2000 and 2010. The most notable feature in this transition is the overall rise of connectivity in intercity and interfirm networks. Although both intercity and interfirm networks are shifting, the urban hierarchy is more stable and steeper than the firm hierarchy. Both intercity and interfirm networks are becoming more connected, but the brokerage/controlling functions in the intercity networks have remained rather centralised, reflecting a mixture of hierarchical and heterarchical processes. We also explored cities and firms at aggregated scales, such as regions and sectors. For the intercity network, regional inequalities among average centralities are decreasing. For the interfirm network, sectoral dynamics are different, with law and consultancy firms achieving aboveaverage growth in centralities.

We explored both modes (i.e. cities and firms) in the intercity corporate network separately. Scope for future extension of this line of research lies in (1) comparing one-mode networks constructed by different projection methods (Neal 2014); (2) exploring centralities of cities and firms simultaneously, with future advancement in direct two-mode network analysis (Borgatti \& Everett 1997); (3) employing advanced network visualisations (Vinciguerra et al., 2010; Liu et al. 2013b); and (4) network normalisation should be employed in future analysis, as direct comparisons of network metrics calculated for networks of different sizes (e.g. the comparison between intercity and interfirm networks) may produce spurious results (van Wijk et al. 2010). In addition, given our focus on methodological refinements to Taylor's (2001) IWCNM, our interpretations of the results have been restricted to conjecture: more substantive understandings, fuelled by qualitative research are therefore 
needed to realise the potential of such a refined methodological approach (Parnreiter 2014; Watson \& Beaverstock 2014). 
Appendix 1. QAP correlation between the original network and the network after applying a threshold (as a proportion of the strongest dyad)

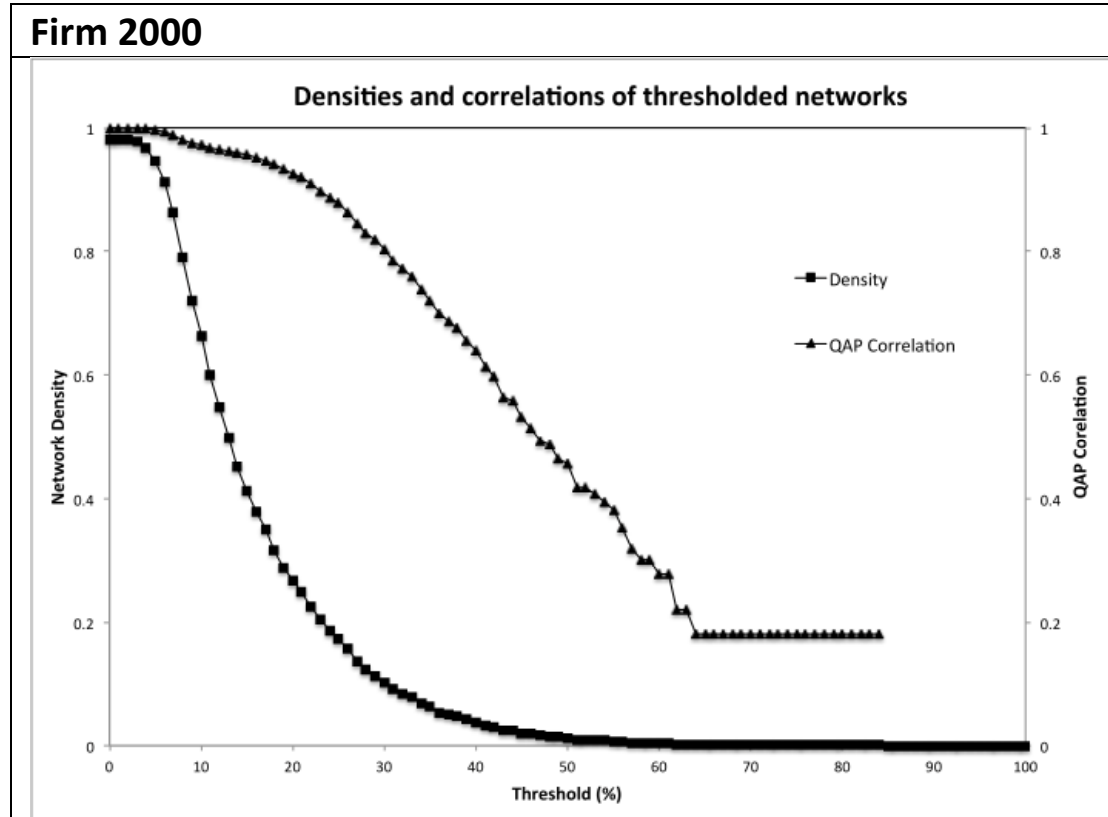
Firm 2010

\section{City 2000}
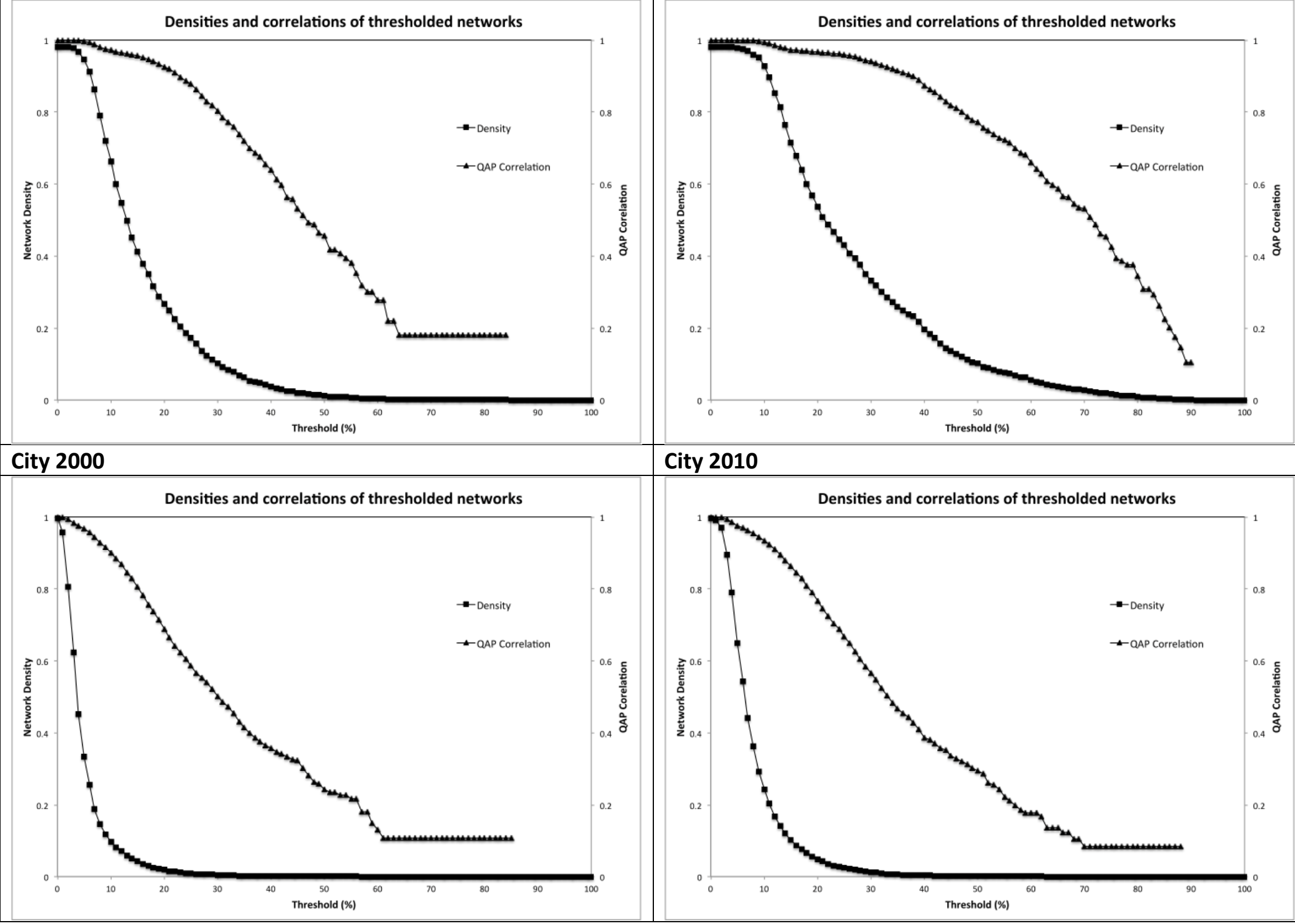

City 2010

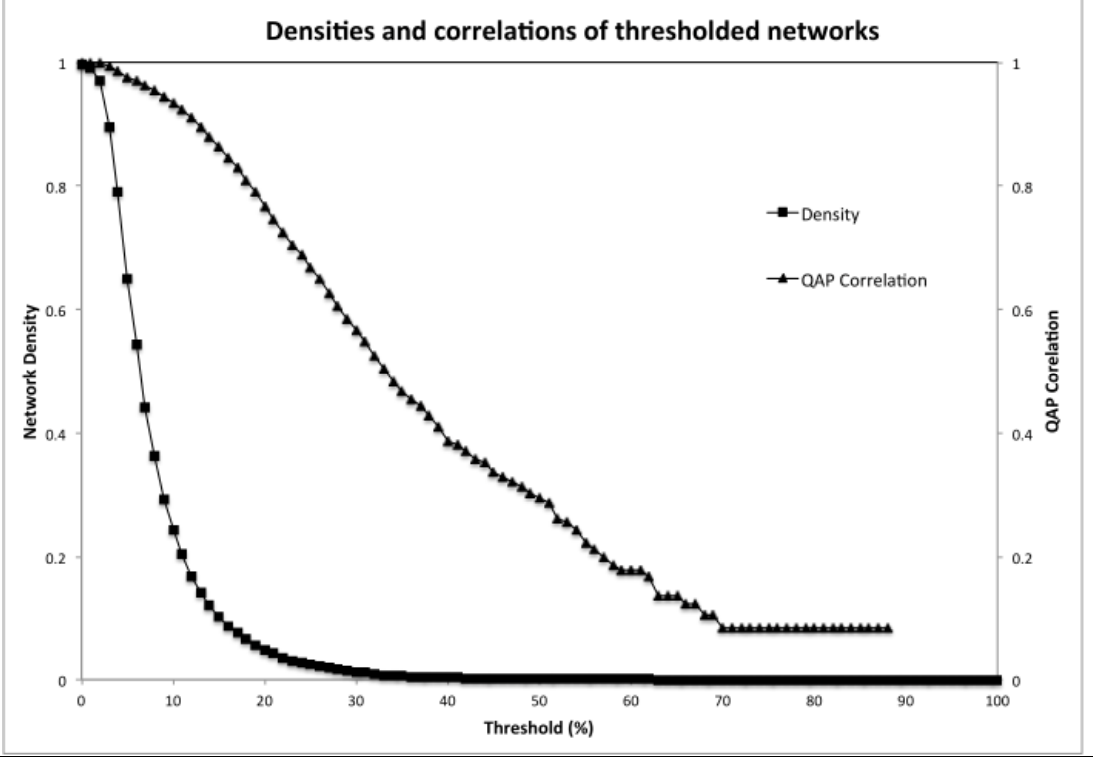


To circumvent the problem of fully connected projected networks, we impose a dichotomisation threshold at 10 per cent of the strongest dyad in original networks. The resulting network has a much lower density, but nonetheless a sizable QAP correlation (with correlation coefficients > 0.9 in most cases; QAP, Quadratic Assignment Procedure, see Hanneman \& Riddle 2005) with the original network: this implies that the structure of dichotomised network closely mimics the structure of the original network, but with a density that only the meaningful or 'strong' links are retained. Other thresholds such as 5 per cent, 15 per cent and 20 per cent have also been tested, and overall trends in the analysis remain, despite that specific orderings of hierarchies may shift with different thresholds.

The number of linkages in thresholded networks are as follows: 2393 (intercity 2000), 5446 (intercity 2010), 800 (interfirm 2000 ), and 1090 (interfirm 2010). The QAP correlation between intercity networks in 2000 and 2010 is 0.5386 , and the QAP correlation between interfirm networks in 2000 and 2010 is 0.3423 . Both correlations are significant at the 0.01 level. 


\section{References}

ALDERSON, A.S., \& J. BECKFIELD (2004), Power and Position in the World City System. American Journal of Sociology 109, pp. 811-851.

ALDERSON, A.S., J. BECKFIELD, \& J. SPRAGUE-JONES (2010), Intercity Relations and Globalization: The Evolution of the Global Urban Hierarchy, 1981-2007. Urban Studies 47, pp.1899-1923.

BATHELT, H., A. MALMBERG, \& P. MASKELL (2004), Clusters and Knowledge: Local Buzz, Global Pipelines and the Process of Knowledge Creation. Progress in Human Geography 28, pp. 31-56.

BECKFIELD, J. \& A.S. ALDERSON (2006), Whither the Parallel Paths? The Future of Scholarship on the World City System. American Journal of Sociology 112, pp, 895-904.

BERRY, B. (1964), Cities as systems within systems of cities. Papers in Regional Science 13, pp. 147-163.

BORGATTI, S.P. \& M.G. EVERETT (1997), Network Analysis of 2-mode Data. Social Networks 19, pp. 243-269.

BREIGER, R.L. (1974), The Duality of Persons and Groups. Social Forces 53, pp. 181-190.

BUTTS, C.T. (2009), Revisiting the Foundations of Network Analysis. Science 325, pp. 414416.

CASTELLS, M. (2001), The Rise of the Network Society. Oxford: Blackwell. 
DERUDDER, B., P. TAYLOR, P. NI, A. DE VOS, M. HOYLER, H. HANSSENS, et al. (2010), Pathways of Change: Shifting Connectivities in the World City Network, 2000-08, Urban Studies 47, pp. 1861-1877.

DUCRUET, C. (2013), Mapping Global Urban Interactions: Maritime Flows and Port Hierarchies since the Late Nineteenth Century. GaWC Research Bulletin, available at http://www.lboro.ac.uk/gawc/rb/rb429.html

FRIEDMANN, J. (1986), The World City Hypothesis. Development and Change 17, pp. 69-83.

HANNEMAN, R. \& RIDDLE, M. (2005), Introduction to Social Network Methods. Riverside, CA: University of California, Riverside.

HENNEMANN, S. \& B. DERUDDER (2013), An Alternative Approach to the Calculation and Analysis of Connectivity in the World City Network. arXiv:1206.6214v1

HOYLER, M., T. FREYTAG, \& C. MAGER (2008), Connecting Rhine-Main: The Production of Multi-Scalar Polycentricities through Knowledge-Intensive Business Services. Regional Studies 42, pp. 1095-1111.

HOYLER, M., \& A. WATSON (2013), Global Media Cities in Transnational Media Networks. Tijdschrift voor Economische en Sociale Geografie 104, pp. 90-108.

HUBER, F. (2012), Do Clusters really Matter for Innovation Practices in Information Technology? Questioning the Significance of Technological Knowledge Spillovers. Journal of Economic Geography 12, 107-126.

JACOBS, W., H. KOSTER, \& P.V. HALL. (2011), The Location and Global Network Structure of Maritime Advanced Producer Services. Urban Studies 48, 2749-2769.

KRÄTKE, S. (2013), How Manufacturing Industries Connect Cities across the World: Extending Research on 'Multiple Globalizations'. Global Networks 14, pp. 121-147. 
LATAPY, M., C. MAGNIEN, \& N. VECCHIO (2008), Basic Notions for the Analysis of Large Twomode Networks. Social Networks 30, pp. 31-48.

LIU, X., \& B. DERUDDER (2012a), Analyzing Urban Networks Through the Lens of Corporate Networks: A Critical Review. Cities 31, 430-437.

LIU, X. \& B. DERUDDER (2012b), Two-mode Networks and the Interlocking World City Network Model: A Reply to Neal. Geographical Analysis 44, pp. 171-173.

LIU, X., B. DERUDDER, Y. LIU, F. WITLOX, W. SHEN (2013a), A Stochastic Actor-based Modelling of the Evolution of an Intercity Corporate Network, Environment and Planning A 45, 947-966.

LIU, X., B. DERUDDER, G. COSMOS, \& P.J. TAYLOR (2013b), Featured Graphic: Mapping Shifting Hierarchical and Regional Tendencies in an Urban Network through Alluvial Diagrams. Environment and Planning A 45, 1005-1007.

MAHUTGA, M., X. MA, D.A. SMITH \& M. TIMBERLAKE (2010), Economic Globalisation and the Structure of the World City System: The Case of Airline Passenger Data. Urban Studies 47, pp. 1925-1947.

MITCHELSON, R.L. \& J.O. WHEELER (1994), The Flow of Information in a Global Economy: the Role of the American Urban System in 1990. Annals of the Association of American Geographers 84, pp. 87-107.

NEAL, Z. (2008), The Duality of World Cities and Firms: Comparing Networks, Hierarchies, and Inequalities in the Global Economy. Global Networks 8, pp. 94-115.

NEAL, Z. (2011), Differentiating Centrality and Power in the World City Network. Urban Studies 48, pp. 2735-2750. 
NEAL, Z. (2012), Structural Determinism in the Interlocking World City Network. Geographical Analysis 44, pp. 162-170.

NEAL, Z. (2013), Brute Force and Sorting Processes: Two Perspectives on World City Network Formation. Urban Studies 50, 1277-1291.

NEAL, Z. (2014), Validity in World City Networks. Tijdschrift voor Economische en Sociale Geografie 105, pp. 427-443.

NORDLUND, C. (2004), A Critical Comment on the Taylor Approach for Measuring World City Interlock Linkages. Geographical Analysis 36, pp. 290-296.

OPSAHL, T., \& P. PANZARASA. (2009), Clustering in Weighted Networks. Social Networks 31, 155-163.

PARNREITER, C. (2014), Network or hierarchical relations? A plea for redirecting attention to the control functions of global cities. Tijdschrift voor Economische en Sociale Geografie 105, pp. 398-411.

POLENSKE, K.R. (2004), Competition, Collaboration, and Cooperation: An Uneasy Triangle in Networks of Firms and Regions. Regional Studies 38, pp. 1029-1043.

ROSSI, E.C., \& P.J. TAYLOR. (2006), 'Gateway Cities' in Economic Globalisation: How Banks are Using Brazilian Cities. Tijdschrift voor Economische en Sociale Geografie 97, pp. 515534.

ROZENBLAT, C. \& D. PUMAIN (2007), Firm Linkages, Innovation and the Evolution of Urban Systems. In: P.J. TAYLOR, B. DERUDDER, P. SAEY, \& F. WITLOX, eds. Cities in Globalization: Practices, Policies, Theories, pp. 124-149. London: Routledge.

RUTHERFORD, J., A. GILLESPIE, \& R. RICHARDSON (2004), The Territoriality of Pan-European Telecommunications Backbone Networks. Journal of Urban Technology 11, pp. 1-34. 
SASSEN, S. (1991), The Global City: New York, London, Tokyo. Princeton, NJ: Princeton University Press.

SMITH, D.A., \& M.F. TIMBERLAKE (2001), World City Networks and Hierarchies, 1977-1997: An Empirical Analysis of Global Air Travel Links. American Behavioral Scientist 44, pp. 16561678.

TAYLOR, P.J. (2001), Specification of the World City Network. Geographical Analysis 33, pp. 181-194.

TAYLOR, P.J. (2004), World City Network: A Global Urban Analysis. London: Routledge.

TAYLOR, P.J., G. CATALANO, \& D.R.F WALKER (2002), Measurement of the World City Network. Urban Studies 39, pp. 2367-2376.

TAYLOR, P., \& B. DERUDDER (2004), Porous Europe: European Cities in Global Urban Arenas. Tijdschrift voor Economische en Sociale Geografie 95, 527-538.

TAYLOR, P.J., B. DERUDDER, M. HOYLER, \& P. NI (2013a), New Regional Geographies of the World as Practised by Leading Advanced Producer Service Firms in 2010. Transactions of the Institute of British Geographers 38, 497-511.

TAYLOR, P.J., B. DERUDDER, M. HOYLER \& P. NI (2014), Advanced Producer Service Firms as Strategic Networks, Global Cities as Strategic Places. Economic Geography, doi: 10.1111/ecge.12040.

TAYLOR, P.J., M. HOYLER, K. PAIN, \& S. VINCIGUERRA (2013b), Extensive and Intensive Globalizations: Explicating the Low Connectivity Puzzle of US Cities Using a City-dyad Analysis. Journal of Urban Affairs, doi: 10.1111/juaf.12077. 
TAYLOR, P.J., M. HOYLER, D.R.F WALKER \& M. SZEGNER (2001), A New Mapping of the World for the New Millennium. The Geographical Journal 167, pp. 213-222.

TAYLOR, P.J., P. NI, B. DERUDDER, M. HOYLER, J. HUANG, \& F. WITLOX, eds., (2011), Global Urban Analysis: A Survey of Cities in Globalization. London: Earthscan.

VINCIGUERRA, S., P.J. TAYLOR, M. HOYLER, \& K. PAIN (2010), Contemporary Mappa Mundi: American Exceptionalism in the World City Network. Environment and Planning A 42, pp. 1271-1272.

WALL, R. (2009), Netscape: Cities and Global Corporate Networks (PhD thesis, Rotterdam: Erasmus Research Institute of Management (ERIM)).

WALL, R., M. BURGER, \& G. A. VAN DER KNAAP (2011), The Geography of Global Corporate Networks: the Poor, the Rich, and the Happy Few Countries. Environment and Planning A 43, pp. 904-927.

WALL, R., \& G.A. VAN DER KNAAP (2011), Sectoral Differentiation and Network Structure Within Contemporary Worldwide Corporate Networks. Economic Geography 87, pp. 267308.

WATSON, A., \& J. BEAVERSTOCK. (2014), World City Network Research at a Theoretical Impasse: On the Need to Re-establish Qualitative Approaches to Understanding Agency in World City Networks. Tijdschrift voor Economische en Sociale Geografie 105, pp. 412-426.

VAN WIJK, B., C. STAM, \& A. DAFFERTSHOFER. (2010), Comparing Brain Networks of Different Size and Connectivity Density Using Graph Theory. PLoS ONE 5, e13701. doi:10.1371/journal.pone.0013701. 


\section{TABLES AND FIGURES}

Table 1. Centrality rankings of cities

\begin{tabular}{|c|c|c|c|c|c|c|}
\hline & Degree & & Closeness & & Betweenness & \\
\hline Rank & City & Score & City & Score & City & Score \\
\hline \multicolumn{7}{|l|}{2000} \\
\hline 1 & New York & 1.0000 & New York & 0.9563 & New York & 0.3098 \\
\hline 2 & London & 0.9932 & London & 0.9503 & London & 0.2973 \\
\hline 3 & Paris & 0.6712 & Paris & 0.7356 & Paris & 0.0285 \\
\hline 4 & Amsterdam & 0.6575 & Amsterdam & 0.7286 & Hong Kong & 0.0250 \\
\hline 5 & Hong Kong & 0.6507 & Hong Kong & 0.7251 & Toronto & 0.0246 \\
\hline 6 & Toronto & 0.6233 & Toronto & 0.7116 & Amsterdam & 0.0226 \\
\hline 7 & Tokyo & 0.5959 & Tokyo & 0.6986 & Tokyo & 0.0117 \\
\hline 8 & Milan & 0.5822 & Milan & 0.6923 & Milan & 0.0101 \\
\hline 9 & Madrid & 0.5685 & Madrid & 0.6861 & Chicago & 0.0098 \\
\hline 10 & Singapore & 0.5685 & Singapore & 0.6861 & Madrid & 0.0078 \\
\hline 11 & Los Angeles & 0.5548 & Los Angeles & 0.6800 & Los Angeles & 0.0072 \\
\hline 12 & Chicago & 0.5479 & Chicago & 0.6770 & Singapore & 0.0072 \\
\hline 13 & Sydney & 0.5411 & Sydney & 0.6740 & Brussels & 0.0055 \\
\hline 14 & Brussels & 0.5342 & Brussels & 0.6711 & Frankfurt & 0.0050 \\
\hline 15 & Sao Paulo & 0.5342 & Sao Paulo & 0.6711 & Sydney & 0.0049 \\
\hline \multicolumn{7}{|l|}{2010} \\
\hline 1 & London & 1.0000 & London & 1.0000 & London & 0.1014 \\
\hline 2 & New York & 0.9869 & New York & 0.9871 & New York & 0.0753 \\
\hline 3 & Hong Kong & 0.9281 & Hong Kong & 0.9329 & Hong Kong & 0.0282 \\
\hline 4 & Paris & 0.9150 & Paris & 0.9217 & Paris & 0.0233 \\
\hline 5 & Singapore & 0.9085 & Singapore & 0.9162 & Dubai & 0.0211 \\
\hline 6 & Dubai & 0.9085 & Dubai & 0.9162 & Chicago & 0.0196 \\
\hline 7 & Chicago & 0.9020 & Chicago & 0.9107 & Singapore & 0.0183 \\
\hline 8 & Sydney & 0.9020 & Sydney & 0.9107 & Sydney & 0.0178 \\
\hline 9 & Amsterdam & 0.8889 & Amsterdam & 0.9000 & Milan & 0.0162 \\
\hline 10 & Mumbai & 0.8889 & Mumbai & 0.9000 & Amsterdam & 0.0150 \\
\hline 11 & Tokyo & 0.8824 & Tokyo & 0.8947 & Mumbai & 0.0149 \\
\hline 12 & Milan & 0.8824 & Milan & 0.8947 & Tokyo & 0.0129 \\
\hline 13 & $\begin{array}{l}\text { Kuala } \\
\text { Lumpur }\end{array}$ & 0.8627 & $\begin{array}{l}\text { Kuala } \\
\text { Lumpur }\end{array}$ & 0.8793 & $\begin{array}{l}\text { Kuala } \\
\text { Lumpur }\end{array}$ & 0.0115 \\
\hline 14 & Toronto & 0.8562 & Toronto & 0.8743 & Toronto & 0.0099 \\
\hline 15 & Sao Paulo & 0.8562 & Sao Paulo & 0.8743 & Sao Paulo & 0.0099 \\
\hline
\end{tabular}


Table 2. Centrality rankings of firms

\begin{tabular}{|c|c|c|c|c|c|c|}
\hline & Degree & & Closeness & & Betweenness & \\
\hline Rank & Firms & Score & Firms & Score & Firms & Score \\
\hline \multicolumn{7}{|l|}{2000} \\
\hline 1 & KPMG & 1.0000 & KPMG & 0.9608 & KPMG & 0.0561 \\
\hline 2 & PwC & 0.9787 & PwC & 0.9423 & $\mathrm{PwC}$ & 0.0558 \\
\hline 3 & Deutsche Bank & 0.9362 & Deutsche Bank & 0.9074 & Mitsubishi UFJ & 0.0442 \\
\hline 4 & Mizuho & 0.9362 & Mizuho & 0.9074 & Deutsche Bank & 0.0246 \\
\hline 5 & McCann Erickson & 0.9362 & McCann Erickson & 0.9074 & Mizuho & 0.0246 \\
\hline 6 & RSM & 0.9362 & RSM & 0.9074 & McKinsey & 0.0245 \\
\hline 7 & Barclays & 0.9149 & Barclays & 0.8909 & McCann Erickson & 0.0218 \\
\hline 8 & AGN & 0.9149 & AGN & 0.8909 & RSM & 0.0218 \\
\hline 9 & Crowe Horwath & 0.9149 & Crowe Horwath & 0.8909 & Barclays & 0.0149 \\
\hline 10 & HLB & 0.9149 & HLB & 0.8909 & $\mathrm{HSBC}$ & 0.0132 \\
\hline 11 & JWT & 0.9149 & JWT & 0.8909 & AGN & 0.0099 \\
\hline 12 & McKinsey & 0.8936 & McKinsey & 0.8750 & Crowe Horwath & 0.0099 \\
\hline 13 & BBDO & 0.8936 & BBDO & 0.8750 & HLB & 0.0099 \\
\hline 14 & PKF & 0.8936 & PKF & 0.8750 & JWT & 0.0099 \\
\hline 15 & BNP Paribas & 0.8936 & BNP Paribas & 0.8750 & BBDO & 0.0082 \\
\hline \multicolumn{7}{|l|}{2010} \\
\hline 1 & KPMG & 1.0000 & KPMG & 1.0000 & KPMG & 0.0065 \\
\hline 2 & McCann Erickson & 1.0000 & McCann Erickson & 1.0000 & McCann Erickson & 0.0065 \\
\hline 3 & HSBC & 1.0000 & HSBC & 1.0000 & HSBC & 0.0065 \\
\hline 4 & BDO & 1.0000 & $\mathrm{BDO}$ & 1.0000 & $\mathrm{BDO}$ & 0.0065 \\
\hline 5 & Deloitte & 1.0000 & Deloitte & 1.0000 & Deloitte & 0.0065 \\
\hline 6 & IBM & 1.0000 & IBM & 1.0000 & IBM & 0.0065 \\
\hline 7 & Baker Tilly & 1.0000 & Baker Tilly & 1.0000 & Baker Tilly & 0.0065 \\
\hline 8 & PwC & 0.9796 & $\mathrm{PwC}$ & 0.9800 & Mitsubishi UFJ & 0.0056 \\
\hline 9 & Mitsubishi UFJ & 0.9796 & Mitsubishi UFJ & 0.9800 & Mizuho & 0.0056 \\
\hline 10 & Deutsche Bank & 0.9796 & Deutsche Bank & 0.9800 & $\mathrm{PwC}$ & 0.0026 \\
\hline 11 & RSM & 0.9796 & RSM & 0.9800 & Deutsche Bank & 0.0026 \\
\hline 12 & AGN & 0.9796 & AGN & 0.9800 & RSM & 0.0026 \\
\hline 13 & HLB & 0.9796 & HLB & 0.9800 & AGN & 0.0026 \\
\hline 14 & PKF & 0.9796 & PKF & 0.9800 & HLB & 0.0026 \\
\hline 15 & Moore Stephens & 0.9796 & Moore Stephens & 0.9800 & PKF & 0.0026 \\
\hline
\end{tabular}

Note: $\mathrm{PwC}=$ PricewaterhouseCoopers 
Table 3. Change of average centrality scores

\begin{tabular}{|l|l|l|l|}
\hline Cities & 2000 & 2010 & COR(2000/2010) \\
\hline Degree & 0.2129 & 0.4623 & 0.8601 \\
\hline Closeness & 0.5600 & 0.6737 & 0.8455 \\
\hline Between & 0.0053 & 0.0035 & 0.9133 \\
\hline & & & \\
\hline Firm & 2000 & 2010 & COR(2000/2010) \\
\hline Degree & 0.6528 & 0.8898 & 0.5907 \\
\hline Closeness & 0.7509 & 0.9141 & 0.5712 \\
\hline Between & 0.0080 & 0.0023 & 0.4008 \\
\hline
\end{tabular}


Table 4. Temporal evolution of hierarchies among cities and firms

\begin{tabular}{|l|l|l|l|}
\hline Cities & Degree & Close & Between \\
\hline 2000 & 56.09 & 11.17 & 95.97 \\
\hline 2010 & 35.3 & 10.87 & 85.44 \\
\hline & & & \\
\hline Firms & Degree & Close & Between \\
\hline 2000 & 23.64 & 10.28 & 73.2 \\
\hline 2010 & 7.79 & 5.45 & 49.31 \\
\hline
\end{tabular}


Table 5. Temporal evolution of hierarchies among regions and sectors

\begin{tabular}{|l|l|l|l|}
\hline Regions & Degree & Close & Between \\
\hline 2000 & 23.85 & 4.72 & 70.99 \\
\hline 2010 & 13.98 & 4.18 & 37.67 \\
\hline & & & \\
\hline Sectors & Degree & Close & Between \\
\hline 2000 & 12.63 & 5.43 & 43.66 \\
\hline 2010 & 5.64 & 3.95 & 30.58 \\
\hline
\end{tabular}


Table 6. Growth rates (\%) for regions

\begin{tabular}{|l|l|l|l|}
\hline $\begin{array}{l}\text { Growth rate 2000- } \\
2010\end{array}$ & Degree & Close & Between $^{7}$ \\
\hline AUSTRALIA & 99.18 & 17.72 & 224.71 \\
\hline EURASIA & 248.10 & 30.20 & 1270.42 \\
\hline EUROPE & 106.94 & 21.26 & -46.28 \\
\hline LATIN AMERICA & 96.52 & 12.68 & 195.27 \\
\hline MENA & 234.57 & 20.73 & 2841.67 \\
\hline NORTH AMERICA & 105.73 & 21.14 & -61.57 \\
\hline PACIFIC ASIA & 88.89 & 26.81 & 100.95 \\
\hline SOUTH ASIA & 215.59 & 22.39 & 1343.40 \\
\hline SUB-SAHARAN AFRICA & 214.80 & 12.67 & 65.36 \\
\hline WORLD & 117.17 & 20.29 & -32.92 \\
\hline
\end{tabular}

\footnotetext{
${ }^{7}$ Note: Regions with growth rate labelled as NA have zero betweenness centrality in 2000.
} 
Table 7 Growth rates (\%) for sectors

\begin{tabular}{|l|l|l|l|}
\hline $\begin{array}{l}\text { Growth rate 2000- } \\
2010\end{array}$ & Degree & Close & Between \\
\hline ACCOUNTING & 24.49 & 19.65 & -72.70 \\
\hline ADVERTISING & 25.26 & 15.18 & -70.88 \\
\hline BANKING & 18.72 & 14.37 & -81.97 \\
\hline CONSULTANCY & 96.52 & 29.97 & -59.86 \\
\hline LAW & 59.65 & 32.58 & -20.80 \\
\hline ALL SECTORS & 36.31 & 21.73 & -71.28 \\
\hline
\end{tabular}


Figure 1. (a) Pedagogical city-by-firm matrix.

\begin{tabular}{lllllll}
\hline \multirow{2}{*}{ City/Firm } & \multicolumn{1}{l}{ Ernst } & \& & & & & \\
Beijing & Young & BBDO & HSBC & Jones Day & Boston \\
\cline { 2 - 6 } London & 0 & 2 & 2 & 0 & 0 \\
New York & 3 & 4 & 5 & 2 & 2 \\
Paris & 5 & 5 & 4 & 4 & 2 \\
Tokyo & 2 & 3 & 4 & 2 & 2 \\
\hline
\end{tabular}

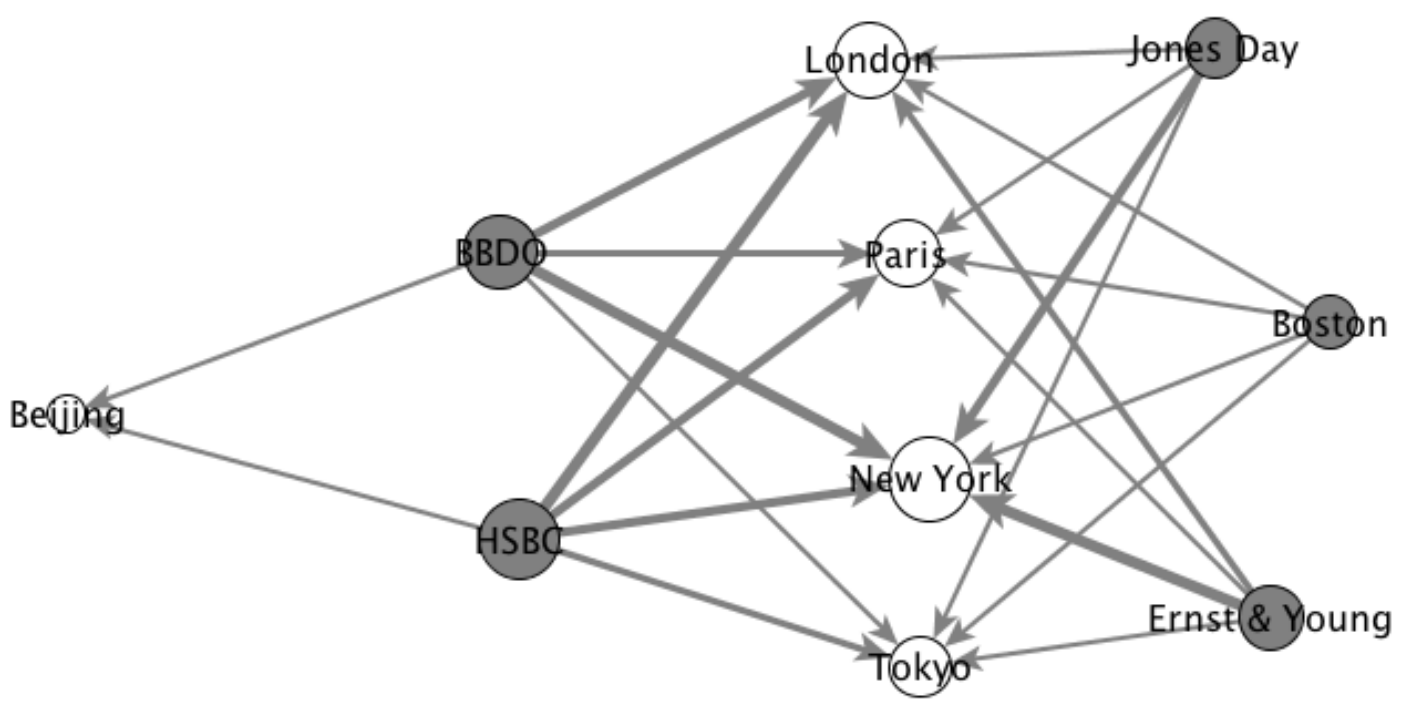

White and grey circles represent cities and firms, respectively. Link width is proportional to the number (total value) of linkages, and the nodal size is proportional to cities' total out degree and in degree. 
Figure 2. Inferred interlocking city network (diagonal elements are set to zero) and its graphical representation.

\begin{tabular}{l|llllll}
\hline \multirow{4}{*}{ Beijing } & Beijing & London & New York & Paris & Tokyo & GCC \\
\cline { 2 - 7 } London & 0 & 18 & 18 & 14 & 10 & 60 \\
New York & 18 & 0 & 67 & 46 & 37 & 168 \\
Paris & 18 & 67 & 0 & 53 & 44 & 182 \\
Tokyo & 14 & 46 & 53 & 0 & 30 & 143 \\
GCC & 10 & 37 & 44 & 30 & 0 & 121 \\
\hline
\end{tabular}

GCC = Global City Connectivity (Equivalent to Global Network Connectivity (GNC) in Taylor 2001), the total number of linkages of individual cities.

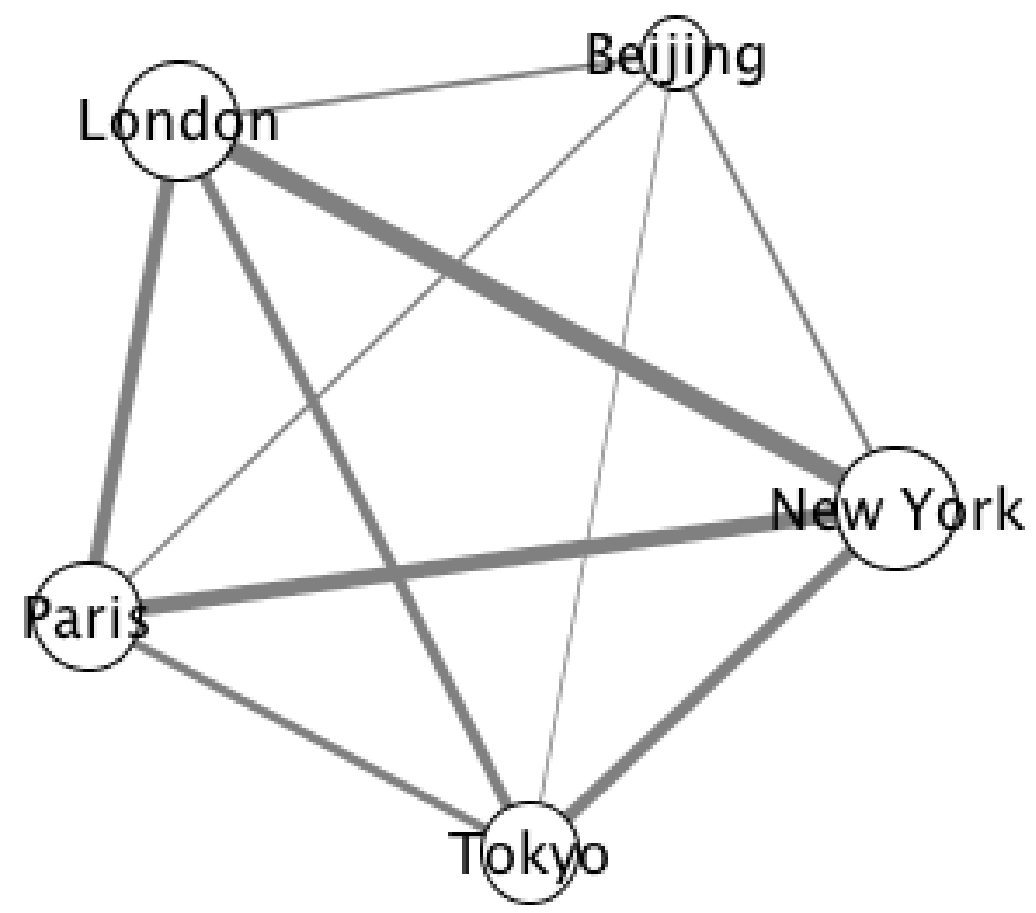

Link width is proportional to the number of linkages, and the nodal size is proportional to cities' GCC. 
Figure 3. Inferred interlocking firm network (diagonal elements are set to zero) and its graphical representation.

\begin{tabular}{l|llllll}
\hline \multirow{2}{*}{ Ernst \& Young } & Ernst \& Young & BBDO & HSBC & Jones Day & Boston & GFC \\
\cline { 2 - 8 } & 0 & 47 & 49 & 34 & 24 & 154 \\
BBDO & 47 & 0 & 62 & 38 & 28 & 175 \\
HSBC & 49 & 62 & 0 & 40 & 32 & 183 \\
Jones Day & 34 & 38 & 40 & 0 & 20 & 132 \\
Boston & 24 & 28 & 32 & 20 & 0 & 104 \\
GFC & 154 & 175 & 183 & 132 & 104 & \\
\hline
\end{tabular}

GFC = Global Firm Connectivity, the total number of linkages of individual firms.

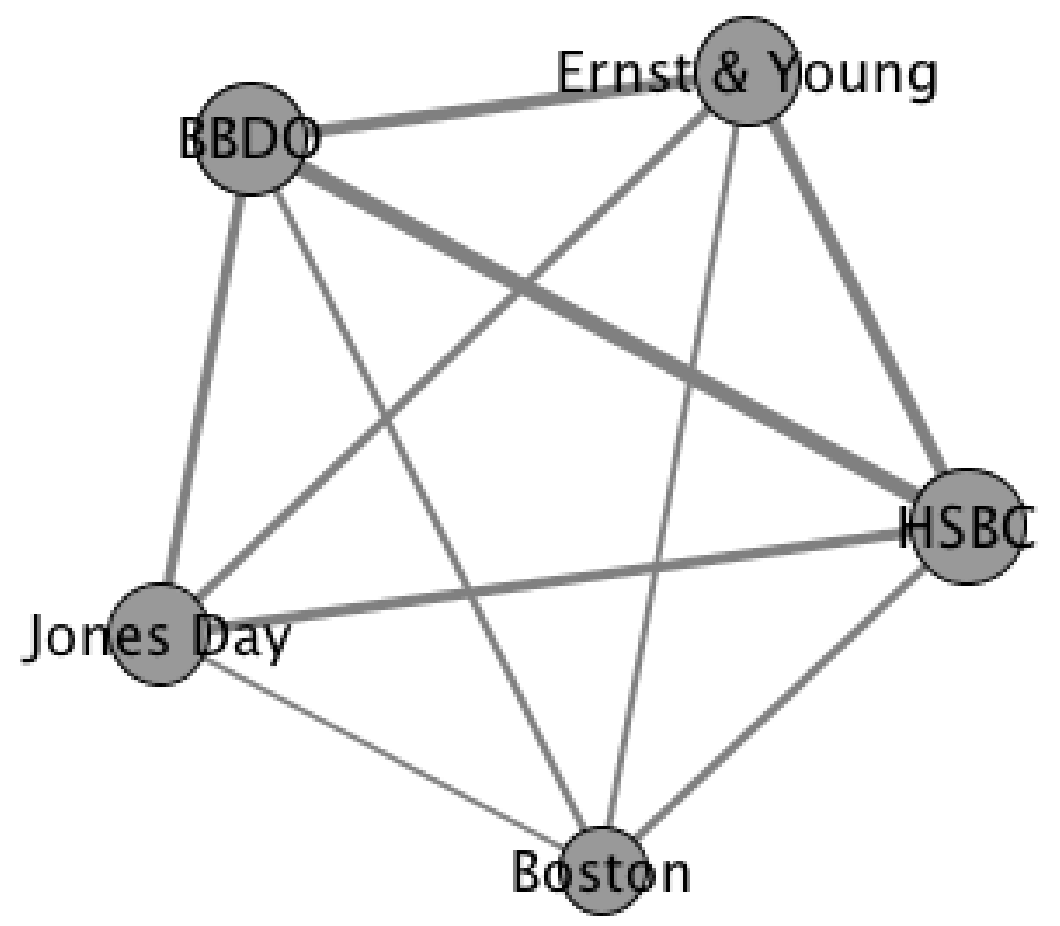

Link width is proportional to the number of linkages, and the nodal size is proportional to firms' GFC. 
Figure 4. Star-like and circle networks

a. Star-like network

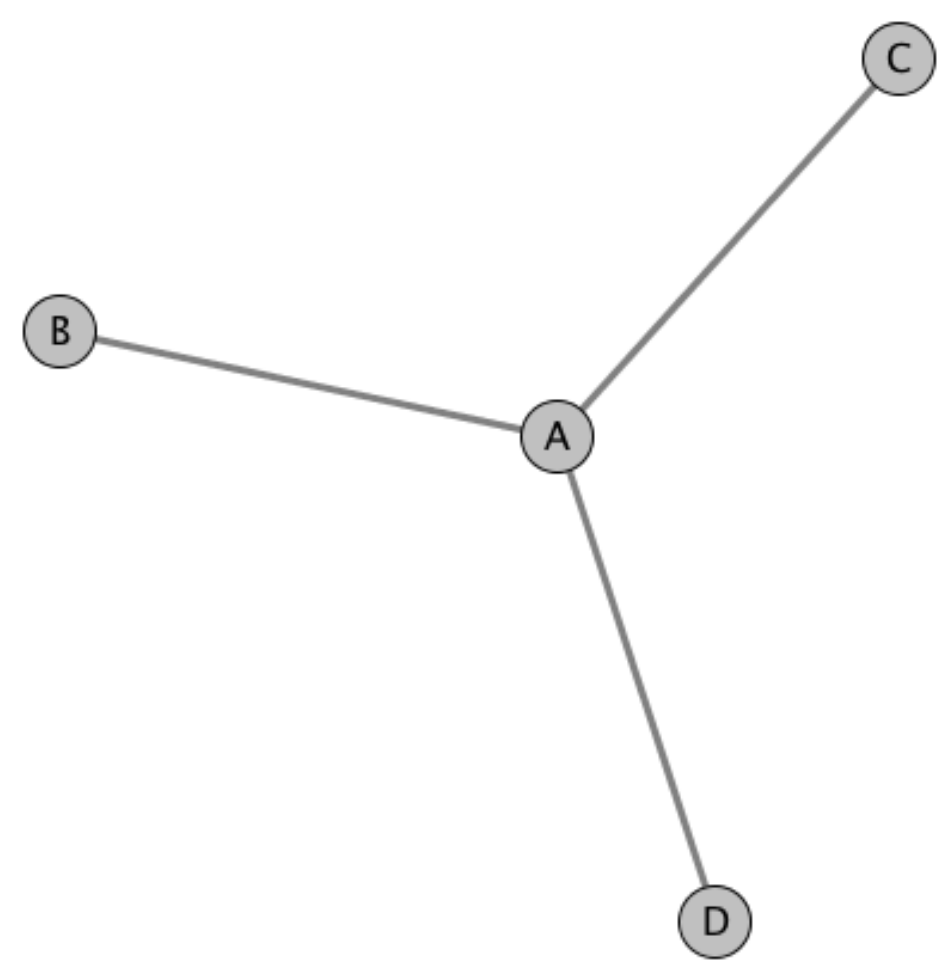

b. Circle network

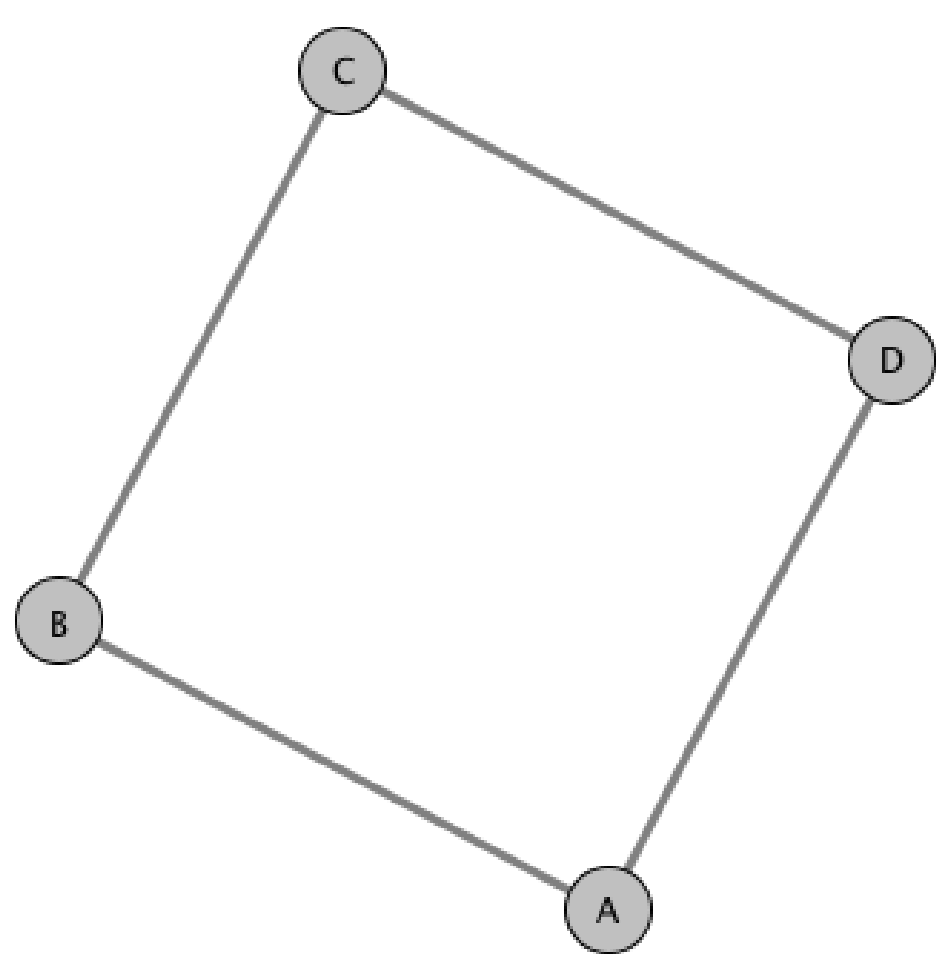

